\title{
TRANSMISSÃO GERACIONAL: REPERCUSSÕES NA ESCOLHA DA PROFISSÃO
}

Kátia Nahum Campos

A adolescência é uma fase do ciclo de vida na qual o sujeito passa por uma série de transformações corporais e psicológicas. Neste período, há a consolidação da identidade e o jovem se depara com uma gama de escolhas que definirão o seu futuro, dentre elas a escolha da profissão. A decisão por uma carreira faz parte de um processo contínuo que começa desde cedo, com uma grande participação da história de vida familiar. Esta pesquisa teve por objetivo analisar a questão da influência da família na escolha profissional, ressaltando aspectos da transmissão geracional.

\section{BANCA:}

Terezinha Féres-Carneiro (Orientadora)

Andrea Seixas Magalhães

Simone Biangolino Rocha

Data da defesa: 26/02/2010 